\title{
STUDI EFEKTIVITAS PENGGUNAAN JEMBATAN PENYEBERANGAN ORANG (JPO) DI KAWASAN LAPANGAN MERDEKA MEDAN (STUDI KASUS : JL. PUTRI HIJAU DAN JL. GURU PATIMPUS)
}

\author{
Marganda Buala Simanjuntak ${ }^{(1)}$, Yulianto ${ }^{(2)}$, Williater Rajagukguk ${ }^{(3)}$ \\ (1) Mahasiswa, Prodi Arsitektur, Fakultas Teknik, Universitas Katolik Santo Thomas Sumatera Utara \\ (2) Staff Pengajar, Prodi Arsitektur, Fakultas Teknik, Universitas Katolik Santo Thomas Sumatera Utara \\ Email: yulianto@ust.ac.id \\ (3) Staff Pengajar, Prodi Arsitektur, Fakultas Teknik, Universitas Katolik Santo Thomas Sumatera Utara
}

\begin{abstract}
Pedestrian Over Pass is one part of the pedestrian path that functions as a pedestrian crossing facility. Pedestrian Over Pass are located on highways with high vehicle intensity and railway lines. As a facility designated for pedestrians, the Pedestrian Over Pass should be effectively used. However, the phenomenon that occurs at this time is that there are many Pedestrian Over Pass that are not used by pedestrians, and they prefer to cross directly. Aside from not being used, many Pedestrian Over Pass are damaged and do not meet the standards of provision. Likewise, what happened in the Merdeka Field area in Medan, there are several Pedestrian Over Pass that are not used and have been damaged and cannot even be accessed. Therefore, researchers are interested in conducting research related to the effectiveness of using the Pedestrian Over Pass in the Merdeka Field area of Medan (Case study: Jalan Putri Hijau and Jalan Guru Patimpus). This study found that the effectiveness of using the Pedestrian Over Pass in research are are Low.
\end{abstract}

Keywords: Pedestrian Over Pass, Pedestrian, Effectivity

\begin{abstract}
Abstrak
Jembatan Penyeberangan Orang (JPO) adalah salah satu bagian dari jalur pedestrian yang berfungsi sebagai fasilitas penyeberangan untuk pejalan kaki. Jembatan Penyeberangan Orang (JPO) terdapat pada jalan raya yang intensitas kendaraannya tinggi dan jalur kereta api. Sebagai fasilitas yang peruntukkan bagi pejalan kaki, seharusnya Jembatan Penyeberangan Orang (JPO) efektif digunakan. Akan tetapi, fenomena yang terjadi saat ini adalah banyak Jembatan Penyeberangan Orang (JPO) yang tidak dipergunakan oleh pejalan kaki, dan mereka lebih memilih untuk menyeberang langsung. Selain tidak digunakan, banyak juga Jembatan Penyeberangan Orang (JPO) yang kondisinya rusak dan tidak memenuhi standar ketentuan penyediaannya. Begitu juga yang terjadi di kawasan Lapangan Merdeka Medan, terdapat beberapa Jembatan Penyeberangan Orang (JPO) yang tidak digunakan dan sudah rusak bahkan tidak dapat diakses. Oleh karena itu, peneliti tertarik untuk melakukan penelitian yang berkaitan dengan efektivitas penggunaan Jembatan Penyeberangan Orang (JPO) di kawasan Lapangan Merdeka Medan (Studi kasus : Jalan Putri Hijau dan Jalan Guru Patimpus). Penelitian ini menemukan bahwa efektivitas penggunaan Jembatan Penyeberangan Orang (JPO) di kawasan kajian adalah Rendah.
\end{abstract}

Kata-kunci : Jembatan Penyeberangan Orang (JPO), Pejalan Kaki, Efektifitas

\section{Pendahuluan}

Kawasan Lapangan Merdeka Kota Medan adalah salah satu kawasan yang paling sering dikunjungi oleh masyarakat Kota Medan. Karena pada kawasan ini banyak terdapat fasilitas-fasilitas publik maupun gedung-gedung perkantoran. Oleh karena itu, setiap hari kawasan ini selalu dikunjungi untuk berbagai kepentingan. Dengan tingginya intensitas kunjungan masyarakat ke kawasan tersebut, maka tentu saja kawasan ini harus memiliki jalur-jalur sirkulasi baik untuk kendaraan bermotor maupun pejalan kaki. 
Selain jalur-jalur sirkulasi, pejalan kaki juga membutuhkan jembatan penyeberangan untuk dapat berpindah dari satu sisi jalan ke sisi jalan lain tanpa menghambat arus pergerakan kendaraan bermotor pada jalan raya. Jembatan penyeberangan adalah salah satu elemen sirkulasi pejalan kaki yang penting, karena menyangkut keamanan dan kenyamanan pejalan kaki. Dalam Tata Cara Perencanaan Jembatan Penyeberangan Untuk Pejalan Kaki di Perkotaan, Departemen Pekerjaan Umum (1995) disebutkan bahwa jembatan penyeberangan pejalan kaki adalah jembatan yang hanya diperuntukkan bagi lalu lintas pejalan kaki yang melintas di atas jalan raya atau jalan kereta api.

Pada umumnya, Jembatan Penyeberangan Orang (JPO) terdapat pada jalan yang memiliki intensitas arus lalu lintas dan arus pejalan kaki yang ramai serta pada rel kereta api. Selain itu penyediaan Jembatan Penyeberangan Orang (JPO) dilakukan ketika penyeberangan zebra tidak dapat diadakan dan penyeberangan pelikan sudah mengganggu lalu lintas kendaraan yang ada, dengan memperhatikan aspek keselamatan, kenyamanan, lokasi, dan estetika dari Jembatan Penyeberangan Orang (JPO) itu sendiri.

Meskipun dalam Undang-Undang Republik Indonesia No. 22 Tahun 2009 Tentang Lalu Lintas dan Angkutan Jalan pasal 132 ayat 1 (a) dan (b) yang menyebutkan bahwa setiap pejalan kaki wajib menggunakan bagian jalan yang diperuntukkan bagi pejalan kaki atau jalan yang paling tepi; atau menyeberang di tempat yang telah ditentukan. Akan tetapi masih banyak pejalan kaki yang tidak mau menggunakan fasilitas tersebut, dan memilih menyeberang jalan raya tanpa menggunakan Jembatan Penyeberangan Orang (JPO). Hal ini tidak jauh berbeda dengan apa yang terjadi di beberapa Jembatan Penyeberangan Orang (JPO) yang terdapat di kawasan Lapangan Merdeka Medan seperti pada Jalan Putri Hijau, dan Jalan Guru Patimpus.

Disamping itu, kondisi fisik dari beberapa Jembatan Penyeberangan Orang (JPO) di kawasan Lapangan Merdeka tersebut sudah tidak memungkinkan untuk digunakan. Beberapa Jembatan Penyeberangan Orang (JPO) tersebut rusak dan usang, bahkan tidak dapat diakses sama sekali.

Permasalahan dalam penelitian ini dirumuskan sebagai berikut : Bagaimana merumuskan keefektifan penggunaan Jembatan Penyeberangan Orang (JPO) di kawasan Lapangan Merdeka Medan? Sehingga tujuan dari penelitian ini adalah :

- Menambah dan memperluas wawasan serta pengetahuan tentang jembatan penyeberangan orang, khususnya pada objek studi jembatan penyeberangan di kawasan Lapangan Merdeka.

- Menemukan nilai efektivitas penggunaan Jembatan Penyeberangan Orang (JPO) di kawasan Lapangan Merdeka Medan.

- Memberikan saran/masukan terhadap keberadaan Jembatan Penyeberangan Orang (JPO) di kawasan Lapangan Merdeka Medan.

\section{Tinjauan Teori}

\subsection{Jembatan Penyeberangan Orang (JPO) \& Efektivitas Penggunaannya}

Pedestrian berasal dari bahasa Yunani pedos yang berarti kaki (Oxford Advance Learner's Dictionary of Current English, A.S Hornby (1998)). Dalam bahasa Inggris, sebagai kata benda, pedestrian berarti "orang yang berjalan kaki" (Kamus Inggris-Indonesia, John dan Hassan, 1982 dalam Rinaldi Mirsa, 2012).

Dengan kata lain, pedestrian juga dapat disebut sebagai kegiatan berjalan kaki. Kegiatan berjalan kaki ini merupakan kegiatan yang dilakukan manusia untuk berpindah dari satu tempat ke tempat lain. Oleh karena itu, kegiatan berjalan kaki tersebut membutuhkan ruang untuk aktivitasnya atau sering disebut sebagai jalur pedestrian.

Menurut Carr (1992; 20) dalam Rinaldi Mirsa, (2012), menyebutkan bahwa jalur pedestrian (pedestrian sidewalks) adalah bagian dari kota di mana orang bergerak dengan kaki, biasanya sepanjang sisi jalan baik yang direncanakan ataupun terbentuk dengan sendirinya, yang menghubungkan satu tempat dengan tempat lainnya. 
Jalur pedestrian pada saat ini menjadi sangat penting, karena hampir semua orang yang melakukan pergerakan atau perpindahan tempat dengan berjalan kaki akan menggunakan fasilitas ini. Jalur pedestrian pada dasarnya harus mampu melindungi pejalan kaki dari pengguna jalur sirkulasi lain misalnya, pengendara kendaraan bermotor pada jalan raya. Selain itu, jalur pedestrian juga harus mampu memberi rasa nyaman bagi penggunanya, kenyamanan tersebut bisa berkaitan dengan kemudahan dalam berjalan kaki, terlindung dari gangguan cuaca, serta ketersediaan informalsi/petunjuk jalan. Dengan demikian jalur pedestrian tidak dapat dipisahkan dari sistem sirkulasi masyarakat di kota-kota besar.

\subsection{Ketentuan Penyediaan Jembatan Penyeberangan Orang (JPO)}

Dalam Tata Cara Perencanaan Jembatan Penyeberangan Untuk Pejalan Kaki di Perkotaan tahun 1995 Departemen Pekerjaan Umum disebutkan bahwa dalam merencanakan Jembatan Penyeberangan Orang (JPO) ada beberapa hal yang perlu diperhatikan, antara lain :

1. Tinggi Ruang Bebas Jembatan Penyeberangan Orang (JPO),

a. Jalan raya yang dilalui bis susun; Tinggi minimal ruang bebas adalah 5,10 $\mathrm{m}$ (terhitung dari tepi bawah gelegar sampai dengan permukaan perkerasan).

b. Jalan raya yang tidak dilalui bis susun; Tinggi minimal ruang bebas adalah 4,60 m (terhitung dari tepi bawah gelegar sampai dengan permukaan perkerasan).

c. Jalan kereta api; Tinggi minimal ruang bebas adalah 6,50 m (terhitung dari tepi bawah gelegar sampai dengan tepi atas kepala rel).

2. Jembatan penyeberangan yang melintas di atas jalan raya :

a. Tangga dan kepala jembatan diletakkan di luar jalur trotoir;

b. Pilar tengah diletakkan ditengah median.

3. Jembatan penyeberangan yang melintas di atas jalan kereta api :

a. Tangga dan kepala jembatan diletakkan di luar daerah milik jalan kereta api;

b. Pilar tengah diletakkan berdasarkan ketentuan instansi yang terkait.

4. Lebar jembatan ditetapkan sebagai berikut :

a. Lebar minimum jalur pejalan kaki dan tangga adalah 2,00 m;

b. Pada kedua sisi jalur pejalan kaki dan tangga harus dipasang sandaran yang mempunyai ukuran sesuai ketentuan yang berlaku;

c. Pada jembatan penyeberangan pejalan kaki yang melintas di atas jalan, sepanjang bagian bawah sisi luar sandaran dapat dipasang elemen yang berfungsi untuk menanam tanaman hias yang bentuk dan dimensinya harus sesuai dengan ketentuan yang berlaku.

5. Tinggi minimum sandaran jembatan penyeberangan untuk pejalan kaki adalah $1,35 \mathrm{~m}$ terhitung mulai dari permukaan lantai sampai dengan tepi atas sandaran.

6. Tinggi tanjakan minimum adalah $15 \mathrm{~cm}$ dan maksimum $21,5 \mathrm{~cm}$.

7. Lebar injakan minimum adalah $21,5 \mathrm{~cm}$ dan maksimum $30,5 \mathrm{~cm}$.

8. Material Jembatan Penyeberangan Orang (JPO) antara lain :
a. Beton
b. Baja
c. Plat Baja
d. Kawat Ram
e. Pipa Logam
f. Aluminium Alloy
g. Plat Fiberglass
h. Pipa PVC

\subsection{Efektivitas Penggunaan Jembatan Penyeberangan Orang (JPO)}

Efektivitas penggunaan Jembatan Penyeberangan Orang (JPO) dapat ditentukan dari pengamatan intensitas penggunaan Jembatan Penyeberangan Orang (JPO) yang dilakukan di jam-jam tertentu pada hari senin, selasa, rabu, kamis, jumat, sabtu, dan minggu. 
Sesuai dengan parameter efektivitas jembatan penyeberangan menurut Listiati Amalia (2005), kriteria penilaian efektivitas penggunaan Jembatan Penyeberangan Orang (JPO) ditinjau dari persentase volume penyeberang yang melalui Jembatan Penyeberangan Orang (JPO) setara dengan pendapat Arikunto Suharsimi, adalah sebagai berikut :

- $\quad 0.800$ s.d. 1.000

adalah tergolong Tinggi

- $\quad 0.600$ s.d. 0.800

- $\quad 0.400$ s.d. 0.600

- $\quad 0.200$ s.d. 0.400

adalah tergolong Cukup Tinggi

- $\quad 0.000$ s.d. 0.200 adalah tergolong Agak Rendah adalah tergolong Rendah adalah tergolong Sangat Rendah

Dengan kata lain, perbandingan antara persentase volume penyeberang dengan nilai efektivitas penggunaan Jembatan Penyeberangan Orang (JPO) adalah sebagai berikut :

Tabel 1. Tabel perbandingan persentase intensitas penyeberang dengan nilai efektivitasnya

\begin{tabular}{ll}
\hline Persentase & Nilai Efektivitas \\
\hline $0 \%-20 \%$ & $0.000-0.200$ \\
\hline $20,01 \%-40 \%$ & $0.200-0.400$ \\
\hline $40,01 \%-60 \%$ & $0.400-0.600$ \\
\hline $60,01 \%-80 \%$ & $0.600-0.800$ \\
\hline $80,01 \%-100 \%$ & $0.800-1.000$ \\
\hline
\end{tabular}

\section{Metode Penelitian}

Metode yang digunakan adalah deskriptif kuantitatif, yang bertujuan menjelaskan hasil pengamatan terhadap intensitas penggunaan dari setiap Jembatan Penyeberangan Orang (JPO) dan kondisi fisik Jembatan Penyeberangan Orang (JPO). Dari hasil pengamatan tersebut, dilakukan analisis yang bertujuan untuk mengetahui nilai efektivitas penggunaan masing-masing Jembatan Penyeberangan Orang (JPO) yang diteliti dan persentase kondisi fisik Jembatan Penyeberangan Orang (JPO).

\section{Metode Pengumpulan Data}

Metode pengumpulan data dibagi 2 (dua) yaitu, data literatur dan data lapangan. Data literatur diperoleh dengan melakukan studi literatur terhadap teori-teori, syarat-syarat, ketentuan-ketentuan, jurnal ilmiah, buku, yang berkaitan dengan Jembatan Penyeberangan Orang (JPO). Sedangkan data lapangan diperoleh dengan melakukan pengamatan, observasi, dan survei yang berkaitan dengan data intensitas penggunaan Jembatan Penyeberangan Orang (JPO) dan kondisi fisik Jembatan Penyeberangan Orang (JPO). Data-data tersebut berupa data tercatat yang berkaitan dengan data-data angka dan data gambar visual Jembatan Penyeberangan Orang (JPO) yang digunakan untuk menjelaskan keadaan eksisting Jembatan Penyeberangan Orang (JPO).

\section{Metode Analisis Data}

Pada tahapan ini, data yang sudah dikompilasikan, kemudian diolah agar dapat diketahui hasilnya. Adapun langkah-langkah analisis data penelitian, sebagai berikut :

- Menghitung data intensitas penggunaan Jembatan Penyeberangan Orang (JPO) dari masingmasing Jembatan Penyeberangan Orang (JPO). 
- Mengubah data angka tersebut kedalam persentase intensitas penggunaan Jembatan Penyeberangan Orang (JPO), yang dinyatakan dalam persen (\%).

- Membandingkan data persentase intensitas penggunaan Jembatan Penyeberangan Orang (JPO) dengan nilai efektivitas penggunaan Jembatan Penyeberangan Orang (JPO).

- Menganalisis kondisi fisik Jembatan Penyeberangan Orang (JPO) di tiap-tiap lokasi penelitian dan membandingkannya dengan kriteria penilaian kondisi fisik berdasarkan ketentuan penyediaan Jembatan Penyeberangan Orang (JPO).

Berikut adalah kriteria penilaian kondisi fisik Jembatan Penyeberangan Orang (JPO).

1. Kenyamanan,

2. Keselamatan,

3. Keamanan,

4. Kenikmatan/Kesenangan.

Kemudian dari hasil penilaian kondisi fisik Jembatan Penyeberangan Orang (JPO) dari masing-masing kriteria dimasukkan ke dalam tabel penilaian total kondisi fisik Jembatan Penyeberangan Orang (JPO) untuk melihat persentase pemenuhan kriteria secara umum.

\section{Analisis Intensitas Penggunaan Jembatan Penyeberangan Orang (JPO) dan Kondisi Fisik Jembatan Penyeberangan Orang (JPO) \\ 1. Analisis Efektivitas Penggunaan Jembatan Penyeberangan Orang (JPO)}

Tabel 2. Nilai efektivitas penggunaan Jembatan Penyeberangan Orang (JPO) Jalan Putri Hijau

\begin{tabular}{lllll}
\hline Hari & Persentase & $\begin{array}{l}\text { Nilai } \\
\text { Efektivitas }\end{array}$ & Keterangan \\
& & 0.200 & - & Rendah \\
Senin & $35,54 \%$ & 0.400 & & \\
& & 0.200 & - & Rendah \\
Selasa & $32,80 \%$ & 0.400 & & \\
& & 0.200 & - & Rendah \\
\hline Rabu & $35,25 \%$ & 0.400 & & \\
& & 0.200 & - & Rendah \\
\hline Kamis & $34,50 \%$ & 0.400 & & \\
& & 0.200 & - & Rendah \\
\hline Jumat & $33,90 \%$ & 0.400 & & \\
& & 0.200 & - & Rendah \\
\hline Sabtu & $36,99 \%$ & 0.400 & & \\
& & 0.200 & - & Rendah \\
\hline Minggu & $27,80 \%$ & 0.400 & \\
& & & & \\
\hline
\end{tabular}

Persentase intensitas penggunaan Jembatan Penyeberangan Orang (JPO) tertinggi adalah hari sabtu yaitu sebesar 36,99\%. Berdasarkan pengamatan yang dilakukan pada saat survei, hal ini dikarenakan meningkatnya kunjungan terhadap beberapa tempat di sekitar Jembatan Penyeberangan Orang (JPO) seperti kawasan Lapangan Merdeka Medan, dimana pada kawasan tersebut sering diadakan kegiatankegiatan yang bersifat publik dan melibatkan orang banyak.

Persentase intensitas terendah adalah hari minggu yaitu sebesar $27,80 \%$. Berdasarkan pengamatan yang dilakukan pada saat survei, hal ini dikarenakan menurunnya kunjungan terhadap beberapa tempat di sekitar Jembatan Penyeberangan Orang (JPO), seperti kawasan Lapangan Merdeka Medan, dimana pada kawasan tersebut intensitas kegiatannya berkurang atau tidak seperti hari sabtu. 
Tabel 3. Nilai efektivitas penggunaan Jembatan Penyeberangan Orang (JPO) Jalan Guru Patimpus

\begin{tabular}{lllll}
\hline Hari & Persentas & $\begin{array}{l}\text { Nilai } \\
\text { Efektivitas }\end{array}$ & Keterangan \\
& $\mathrm{e}$ & \multicolumn{2}{l}{. } & \\
\hline Senin & $28,80 \%$ & 0.200 & - & Rendah \\
& & 0.400 & & \\
\hline Selasa & $29,23 \%$ & 0.200 & - & Rendah \\
& & 0.400 & & \\
\hline Rabu & $27,30 \%$ & 0.200 & - & Rendah \\
& & 0.400 & & \\
\hline Kamis & $27,54 \%$ & 0.200 & - & Rendah \\
& & 0.400 & & \\
\hline Jumat & $23,81 \%$ & 0.200 & - & Rendah \\
& & 0.400 & & \\
\hline Sabtu & $17,31 \%$ & 0.000 & - & Sangat \\
& & 0.200 & Rendah \\
& & & & \\
\hline Minggu & $16,40 \%$ & 0.000 & Sangat \\
& & 0.200 & Rendah \\
\hline
\end{tabular}

Persentase intensitas penggunaan Jembatan Penyeberangan Orang (JPO) tertinggi adalah hari selasa yaitu sebesar 29,23\%. Berdasarkan pengamatan yang dilakukan pada saat survei, hal ini dikarenakan meningkatnya aktivitas pekerja yang bekerja pada proyek sebuah perusahaan pengembang yang berada tidak jauh dari Jembatan Penyeberangan Orang (JPO).

Persentase intensitas terendah adalah hari minggu yaitu sebesar $16,40 \%$. Berdasarkan pengamatan yang dilakukan pada saat survei, hal ini dikarenakan menurunnya aktivitas pekerja yang bekerja pada proyek sebuah perusahaan pengembang yang berada tidak jauh dari Jembatan Penyeberangan Orang (JPO).

\section{Analisis Kondisi Fisik Jembatan Penyeberangan Orang (JPO)}

Tabel 4. Kondisi Fisik Jembatan Penyeberangan Orang (JPO) Jalan Putri Hijau

\begin{tabular}{|c|c|c|c|c|}
\hline \multicolumn{4}{|c|}{ Pemenuhan Kriteria } & \multirow{2}{*}{$\begin{array}{l}\text { Total } \\
\text { Pemenuhan } \\
\text { Kriteria }\end{array}$} \\
\hline Kenyamanan & Keselamatan & Keamanan & $\begin{array}{l}\text { Kenikmatan } \\
\text { / Kesenangan }\end{array}$ & \\
\hline $66,8 \%$ & $80 \%$ & $75 \%$ & $0 \%$ & $55,45 \%$ \\
\hline
\end{tabular}

Total pemenuhan kriteria penilaian kondisi fisik Jembatan Penyeberangan Orang (JPO) adalah sebesar $55,45 \%$. Tidak terpenuhinya nilai $100 \%$ pada penilaian kondisi fisik Jembatan Penyeberangan Orang (JPO) di jalan Putri Hijau (Hotel Inna Dharma Deli - Kantor Pos Indonesia, Medan) menunjukkan bahwa kondisi fisik Jembatan Penyeberangan Orang (JPO) tidak sesuai dengan ketentuan penyediaan Jembatan Penyeberangan Orang (JPO), serta mempengaruhi penggunaan Jembatan Penyeberangan Orang (JPO) oleh pengguna/pejalan kaki. 
Tabel 5. Kondisi Fisik Jembatan Penyeberangan Orang (JPO) Jalan Guru Patimpus

\begin{tabular}{|c|c|c|c|c|}
\hline \multicolumn{4}{|c|}{ Pemenuhan Kriteria } & \multirow{2}{*}{$\begin{array}{l}\text { Total } \\
\text { Pemenuhan } \\
\text { Kriteria }\end{array}$} \\
\hline $\begin{array}{l}\text { Kenyamana } \\
\text { n }\end{array}$ & $\begin{array}{l}\text { Keselamata } \\
\text { n }\end{array}$ & Keamanan & $\begin{array}{l}\text { Kenikmatan } \\
\text { / Kesenangan }\end{array}$ & \\
\hline $50,1 \%$ & $80 \%$ & $0 \%$ & $0 \%$ & $32,53 \%$ \\
\hline
\end{tabular}

Total pemenuhan kriteria penilaian kondisi fisik Jembatan Penyeberangan Orang (JPO) adalah sebesar $32,53 \%$. Tidak terpenuhinya nilai $100 \%$ pada penilaian kondisi fisik Jembatan Penyeberangan Orang (JPO) di jalan Guru Patimpus menunjukkan bahwa kondisi fisik Jembatan Penyeberangan Orang (JPO) tidak sesuai dengan ketentuan penyediaan Jembatan Penyeberangan Orang (JPO), serta mempengaruhi penggunaan Jembatan Penyeberangan Orang (JPO) oleh pengguna/pejalan kaki.

\section{Kesimpulan}

a. Jembatan Penyeberangan Orang (JPO) di Jalan Putri Hijau (Hotel Inna Dharma Deli Kantor Pos Indonesia, Medan)

- $\quad$ Berdasarkan analisa yang telah dilakukan sebelumnya, diketahui bahwa efektivitas penggunaan Jembatan Penyeberangan Orang (JPO) di jalan Putri Hijau (Hotel Inna Dharma Deli - Kantor Pos Indonesia, Medan) adalah Rendah.

- $\quad$ Persentase kriteria terpenuhi terhadap kondisi fisik Jembatan Penyeberangan Orang (JPO) di jalan Putri Hijau (Hotel Inna Dharma Deli - Kantor Pos Indonesia, Medan) adalah sebesar 55,45\%. Hal ini menunjukkan bahwa kondisi Jembatan Penyeberangan Orang (JPO) tersebut tidak memenuhi persentase $100 \%$ dari kriteria kondisi fisik Jembatan Penyeberangan Orang (JPO) yang didasarkan pada ketentuan penyediaan Jembatan Penyeberangan Orang (JPO).

- $\quad$ Nilai persentase 55,45\% tersebut menunjukkan kondisi fisik Jembatan Penyeberangan Orang (JPO) berpengaruh terhadap rendahnya intensitas penggunaan Jembatan Penyeberangan Orang (JPO). Hal ini dapat diketahui dengan mengamati kondisi fisik Jembatan Penyeberangan Orang (JPO) yang :

1. Tidak memiliki jalur penyandang cacat,

2. Terdapat papan iklan yang menutupi hampir seluruh bagian Jembatan Penyeberangan Orang (JPO) sehingga pengguna merasa tidak aman dari tindak kriminal (berdasarkan wawancara langsung dengan pengguna/pejalan kaki),

3. Kelandaian tangga yang lebih dari $10 \%$ membuat pengguna/pejalan kaki merasa lelah untuk menggunakan Jembatan Penyeberangan Orang (JPO) (berdasarkan wawancara langsung dengan pengguna/pejalan kaki),

4. Lokasi Jembatan Penyeberangan Orang (JPO) yang berada lebih dari $50 \mathrm{~m}$ (Sesuai ketentuan penyediaan Jembatan Penyeberangan Orang (JPO)) membuat pengguna/pejalan kaki menjadi malas dalam menggunakan Jembatan Penyeberangan Orang (JPO) itu sendiri (berdasarkan wawancara langsung dengan pengguna/pejalan kaki).

5. Sebagian besar plat lantai yang terbuat dari baja kondisinya berkarat dan rusak sehingga pengguna/pejalan kaki merasa tidak aman, nyaman, dan selamat ketika menggunakan Jembatan Penyeberangan Orang (JPO) tersebut (berdasarkan wawancara langsung dengan pengguna/pejalan kaki) dsb. 


\section{b. Jembatan Penyeberangan Orang (JPO) di Jalan Guru Patimpus}

- $\quad$ Berdasarkan analisa yang telah dilakukan sebelumnya, diketahui bahwa efektivitas penggunaan Jembatan Penyeberangan Orang (JPO) di Guru Patimpus adalah Rendah.

- $\quad$ Persentase kriteria terpenuhi terhadap kondisi fisik Jembatan Penyeberangan Orang (JPO) di jalan Guru Patimpus adalah sebesar 32,53\%. Hal ini menunjukkan bahwa kondisi Jembatan Penyeberangan Orang (JPO) tersebut tidak memenuhi persentase $100 \%$ dari kriteria kondisi fisik Jembatan Penyeberangan Orang (JPO) yang didasarkan pada ketentuan penyediaan Jembatan Penyeberangan Orang (JPO).

- $\quad$ Nilai persentase $32,53 \%$ tersebut menunjukkan kondisi fisik Jembatan Penyeberangan Orang (JPO) mempengaruhi rendahnya intensitas penggunaan Jembatan Penyeberangan Orang (JPO). Hal ini dapat diketahui dengan mengamati kondisi fisik Jembatan Penyeberangan Orang (JPO) yang :

1. Tidak memiliki jalur penyandang cacat,

2. Terdapat papan iklan yang menutupi seluruh bagian Jembatan Penyeberangan Orang (JPO) sehingga pengguna merasa tidak aman dari tindak kriminal (berdasarkan wawancara langsung dengan pengguna/pejalan kaki),

3. Kelandaian tangga yang lebih dari $10 \%$ membuat pengguna/pejalan kaki merasa lelah untuk menggunakan Jembatan Penyeberangan Orang (JPO) (berdasarkan wawancara langsung dengan pengguna/pejalan kaki),

4. Lokasi Jembatan Penyeberangan Orang (JPO) yang berada lebih dari $50 \mathrm{~m}$ (Sesuai ketentuan penyediaan Jembatan Penyeberangan Orang (JPO)) membuat pengguna/pejalan kaki menjadi malas dalam menggunakan Jembatan Penyeberangan Orang (JPO) itu sendiri (berdasarkan wawancara langsung dengan pengguna/pejalan kaki).

5. Sebagian besar plat lantai yang terbuat dari baja kondisinya berkarat dan rusak sehingga pengguna/pejalan kaki merasa tidak aman, nyaman, dan selamat ketika menggunakan Jembatan Penyeberangan Orang (JPO) tersebut (berdasarkan wawancara langsung dengan pengguna/pejalan kaki) dsb.

\section{Saran}

- $\quad$ Perlu adanya perbaikan kondisi fisik pada masing-masing Jembatan Penyeberangan Orang (JPO) untuk meningkatkan intensitas penggunaannya.

- $\quad$ Ketentuan penyediaan Jembatan Penyeberangan Orang (JPO) seharusnya menjadi acuan penting yang tidak boleh diabaikan, sehingga Jembatan Penyeberangan Orang (JPO) tersebut dapat berfungsi sebagaimana mestinya.

- Untuk perencanaan Jembatan Penyeberangan Orang (JPO) di masa akan datang, lebar jalan, intensitas kendaraan bermotor dan lokasi Jembatan Penyeberangan Orang (JPO) harus menjadi perhatian lebih bagi perencana, agar Jembatan Penyeberangan Orang (JPO) dapat benar-benar digunakan.

\section{Daftar Pustaka}

Amalia. Listiati. 2005. KAJIAN EFEKTIFITAS JEMBATAN PENYEBERANGAN PEJALAN KAKI PADA PUSAT PERDAGANGAN DI KOTA SEMARANG. Tesis. Program Pasca Sarjana. Universitas Diponegoro. Semarang. <http://eprints.undip.ac.id/12063/>, 25 Agustus 2015

Amelinda K.P. Pinkan dan Zulkaidi. Denny. 2012. FAKTOR YANG MEMPENGARUHI PENGGUNAAN JEMBATAN PENYEBERANGAN ORANG (JPO) DI KOTA BANDUNG (STUDI KASUS : JPO PADA JALAN ARTERI DAN KOLEKTOR $D I \quad K O T A \quad B A N D U N G)$. SAPPK. Institut Teknologi Bandung. <http://sappk.itb.ac.id/jpwk1/wpcontent/uploads/2014/04/97-106.pdf>, 02 Agustus 2015

Anggriani, Niniek. 2009. Pedestrian Ways Dalam Perancangan Kota. Humaniora. Klaten

Departemen Pekerjaan Umum, Tata Cara Perencanaan Jembatan Penyeberangan Untuk Pejalan Kaki di Perkotaan tahun 1995

Mirsa , Rinaldi. 2012. Elemen Tata Ruang Kota. Graha Ilmu. Yogyakarta

Peraturan Menteri Pekerjaan Umum No. 03/PRT/M/2014 Tentang Pedoman Perencanaan, Penyediaan, dan Pemanfaatan Prasarana dan Sarana Jaringan Pejalan Kaki di Kawasan Perkotaan

Rapoport , Amos. 1977. Human Aspect Of Urban Form. Pergamon. University of Winconsin-Milwaukee 
Setiawan, Rudy. 2006. FAKTOR-FAKTOR YANG MEMPENGARUHI PEMANFAATAN JEMBATAN PENYEBERANGAN. Simposium IX FSTPT. Universitas Brawijaya. <http://fportfolio.petra.ac.id/user files/01-065/Faktorfaktor\%20Yang\%20Mempengaruhi\%20Pemanfaatan\%20Jembatan\%20Penyeberangan.pdf>. 02 Agustus 2015

Supriyadi, Bambang dan Setyo Muntohar, Agus. 2007. Jembatan. Beta Offset. Yogyakarta

Undang-Undang Republik Indonesia No. 22 Tahun 2009 Tentang Lalu Lintas dan Angkutan Jalan 